\title{
Green Industry Survey of Native Plant Marketing in the Southeastern United States
}

\author{
Robert F. Brzuszek ${ }^{1}$ and Richard L. Harkess ${ }^{2,3}$
}

\begin{abstract}
ADDITIONAL INDEX WORDS. market, landscape projects, education, nursery production

SUMMARY. Recent studies have shown that the use of native plants by landscape architects and contractors in the southeastern United States has increased as has the clientele interest level in native plants. Recommendations to increase the use of native species by the landscape industry in this region include increasing the number of nurseries carrying native plants and the quantities and species currently available. To understand how green industry professionals view the opportunities and constraints of the current southeastern United States native plant market and to synthesize the connections between landscape architect's demands and the supplies of the nursery industry in this region, a questionnaire was developed and e-mailed to southeastern U.S. wholesale and retail nurseries in six states. The survey included questions regarding nursery stock, demand, and species sold. A total of 129 responses were received, and they revealed that while there is a perceived increase in customer interest in native plants, market demand and enhanced public education play a key role in further development of this growing market.
\end{abstract}

A recent trend in the United States has been the branding of native plant species and cultivars. The American Beauties ${ }^{\mathrm{TM}}$ Collection was introduced in Spring 2006 through a partnership between the National Wildlife Federation (NWF) and several commercial nurseries, and offers a collection of recommended native plant species for specific garden types, including bird, butterfly, dry shade, and moist sun gardens (NWF, 2007). Currently marketed in the northeastern United States, over 70 independent garden centers are carrying the American Beauties $^{\text {тM }}$ brand label. The NWF's plan is to expand this regional effort to other parts of the country in the near future. Similarly, the Missouri Department of Conservation and Missouri Department of Agriculture launched the Grow Native! program that provides industry-wide branding and tag materials for native plant species. Bench cards, native landscape brochures, industry and public education programs, marketing assistance

\footnotetext{
Mississippi Agriculture and Forestry Experiment Station Journal Series No. J-11336

${ }^{1}$ Department of Landscape Architecture, Mississippi State University, Box 9725, Mississippi State, MS 39762

${ }^{2}$ Department of Plant and Soil Sciences, Mississippi State University, 117 Dorman, Box 9555, Mississippi State, MS 39762

${ }^{3}$ Corresponding author. E-mail: rharkess@pss.msstate. edu.
}

for growers, and pot tags are made available and distributed through the state agency (Hamill, 2005).

Nursery associations and nonprofit conservation organizations also promote native plants and their availability within their state or region. The Association of Florida Native Nurseries (AFNN) is a nonprofit organization that promotes the growing and marketing of native plants indigenous to Florida's ecosystems (Hamill, 2005). The AFNN provides publicly available listings for wholesale and retail nurseries and the native plant species that they carry. Other sections of the country provide similar websites. Calflora is a digital library of native and non-native plants found in California, and was instrumental in the formation of the California Native Plant Link Exchange (CNPLX). The CNPLX is a collection of links to websites of regional retail and wholesale nurseries that carry native species. The AFNN and the CNPLX are query-based websites that can link to nursery listings and plant culture information through the use of plant species names.

Previous research by the authors (Brzuszek et al., 2007) evaluated the use of native plants by landscape architects in the southeastern United States. In this study, we determined that despite a relatively low percentage of their clients specifically requesting native plant material, designers are using a significant proportion of regional native species in their projects. Landscape architects are selecting native species that are better suited to difficult or unique site conditions rather than for ecological reasons. The retail plant buyers in the southeastern region who purchase native plants are primarily influenced by landscape architects and contractors (Waterstrat, 1997). As a result, it "is imperative to keep [clientele] (landscape architects, landscape contractors, and nurserymen) wellinformed about the appropriate use of native trees and plants" (Smith, 2007). Smith (2007) also found the demand for native plants in the southeast region exceeds the supply. Too few wholesale nurseries offer native plant materials, or they are insufficient in quantity or species availability.

Norcini (2006) estimated that native plant sales in Florida were $\approx 11 \%$ of all ornamental products produced in 2005 , or worth roughly $\$ 316$ million. He notes that many native species are unavailable or are in limited supply from southeastern U.S. nurseries for the following reasons: 1) the market is more localized for native plants than exotics, 2) nurseries that specialize in natives are small and lack capital, 3 ) funding to promote the use of native plants is limited, 4) native plants often are more expensive than non-natives, 5) native seed stock is more expensive due to demand, and 6) it is perceived that native plants lack the prestige of exotic species.

If landscape architects are the primary drivers of native plant sales in the southeastern United States, what impact does that have upon wholesale nursery growers and the retail market? What is the potential of the native plant market in this region and what are the best ways of fostering its growth? The objective of this study was to understand how green industry professionals view the opportunities and constraints of the current southeastern native plant market, and to synthesize the connections between landscape architects' demands and the supplies of the nursery industry in this region.

\section{Materials and methods}

An e-mail survey was developed for wholesale and retail nursery owners in the southeastern region of the 
United States, and members of the Southern Nursery Association (SNA) were targeted as a population group that represents established professional horticulture members. Conducting surveys via e-mail has become a popular and proven method for obtaining data as it is typically low cost, offers greater speed for sending and returning surveys, and stimulates higher response levels than mailed surveys (Schaefer and Dillman, 1998). Disadvantages for using e-mail surveys include that some populations do not have e-mail access, do not appreciate unsolicited e-mails, and e-mail lists can be quickly outdated. E-mail surveys have been shown to work well in the business environment, as most corporations have e-mail access.

The e-mail addresses of members of the SNA were randomly selected from their online membership directory in Georgia, Alabama, Mississippi, Louisiana, South Carolina, and Texas. These southern states were selected to provide consistency for collected plant species data because the majority of their land areas fall within zones 7 and 8 of the U.S. Department of Agriculture (USDA) Plant Hardiness Zone Map. Survey questionnaires were e-mailed to 344 SNA members in the southeastern region on 15 June 2007. There are approximately 1800 members of SNA (although many members are outside of the target states), and the initial survey mailing results in a sample of $20 \%$ of that population. The e-mail included a short paragraph explaining the objective of the research and instructions for returning the completed questionnaire. The questionnaire contained 20 numbered questions in closed-and open-ended formats and asked the respondents' perceptions about their use of native plants and business demographic information (Table 1).

A total of 344 e-mail surveys was sent. Of these, 83 e-mails were undeliverable to their listed addresses. A follow up e-mail was sent on 31 Aug. 2007. As recommended by Dillman (2000), a third reminder e-mail was sent on 17 Sept. 2007 to any nonrespondents to the second e-mail to provide a last request for the survey response. The collected survey information was analyzed using SPSS (version 15.0; SPSS Inc., Chicago)

Table 1. Questions included on the 2007 southeastern United States green industry survey on native plant marketing.

1. Does your business sell plant materials that are native to your area?

2. What is your type of business? (retail, wholesale, contracting, maintenance, etc.)

3. How do you indicate the plants that you carry are native?

4. What proportion of your stock is native plant material?

5 . What proportion of your customers specifically request native plant material?

6. What would best increase the volume of your native plant sales?

7. What characterizes the most frequent purchaser of native plants? (residential, government agencies, landscape architects/contractors)

8 . What is the primary reason you carry or sell native plants?

9. Why are native plants purchased by your customers?

10. How do you learn about new types or cultivars of native plants?

11. How do you best learn about new types or cultivars of native plants?

12. Why does your business not sell more native plant materials?

13. What are the top 10 native plant species that you sell?

14. What was the overall customer interest in native plants five years ago?

15. What is the overall customer interest in native plants today?

16. What would be most beneficial for your business to sell more native plants? (plant tags, bench tags, brochures, posters, websites, etc.)

17. What is the population where your business is located?

18. What is your current position? (owner, manager, staff, other)

19. For how many years has your business operated?

20. What was the approximate dollar value of native plants sold in 2006 ?

frequency and crosstab analysis of the response data for all questions.

\section{Results and discussion}

Return e-mail responses were received from 151 nursery professionals from the $261 \mathrm{e}$-mails successfully sent to SNA members in the southeastern United States $(57.8 \%$ response rate). Twenty-two surveys were unusable as respondents declined to participate, resulting in $\mathrm{n}=129$. Texas nurseries returned the most surveys $(24.8 \%)$, followed by Mississippi (19.4\%), Alabama (15.5\%), South Carolina and Louisiana (14\% each), and Georgia (12.4\%); thus, the Texas responses may have more influence on the results relevant to states with less returns. Of these 129 respondents, the majority of the surveys was completed by owners or managers of the firms $(87.6 \%)$ who had been in business for over 10 years $(72.6 \%)$. This signifies that the majority of returned surveys was conducted by those in responsible positions with appreciable experience. Thirteen $(10.1 \%)$ responded that their nursery did not carry native plants (i.e., specializing in groundcovers or specialty plants), but completed portions of the survey regarding trends, education, and demographics. Most respondents classified their business as a wholesale nursery $(\mathbf{5 5 . 8 \% )}$, followed by retail $(25.6 \%)$, and other $(7 \%)$. The majority of businesses was located in rural areas or small towns of less than $100,000(56.7 \%)$, with $19.7 \%$ being located in population centers exceeding 100,000 people (Table 2).

When asked if the plants carried in their nursery were labeled in any way as being native to their area, half $(50.4 \%)$ answered they were not labeled as native in any way $(\mathrm{SD}=$ 1.335). This was nearly identical to Waterstrat's survey of southeastern nursery growers in 1997, which listed $50.3 \%$ of all native plants carried as not being labeled as native (Waterstrat, 1997). Twenty-one percent of the current survey identified natives on the container label, and a few had areas set aside as natives or as being arranged by environmental location preference $(2.3 \%)$. Most survey respondents answered that native species comprise less than $20 \%$ of their stock (Fig. 1), with the exception of Texas respondents, who more frequently listed $21 \%$ to $40 \%$ of their stock as native (state data not shown). When asked what would help increase sales of native plants through their business, better consumer education was the top answer for what would be most beneficial $(54.3 \%)$, followed by the use of individual container tags $(22.3 \%)$, native plant brochures 
Table 2. Demographic characteristics by state of respondents to a southeastern United States green industry survey on native plant marketing conducted in 2007.

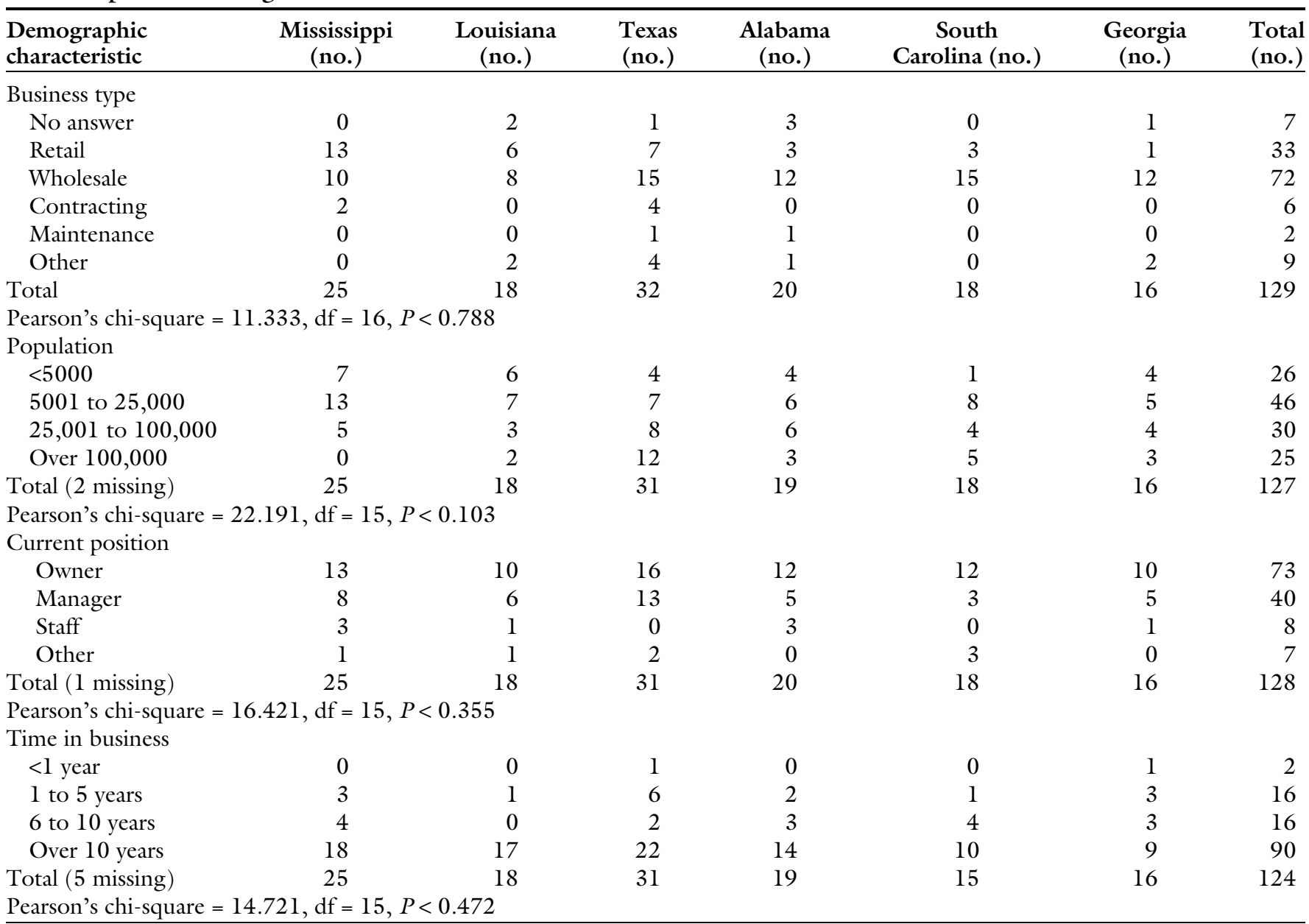

$(12.4 \%)$, or some combination of the above $(S D=1.907)$.

Only a small proportion of their customers specifically asked for native species. Nearly half answered that customers ask for natives less than $20 \%$ of the time, which was a similar response rate as found in the survey of southeastern U.S. landscape architects (Brzuszek et al., 2007). A few respondents noted that customers were typically more concerned with

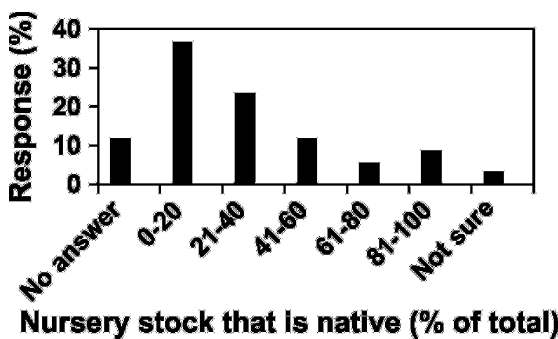

Fig. 1. Percentage of native plants grown or offered in southeastern U.S. nurseries in $2007(\mathrm{SD}=\mathbf{1 . 5 6 4})$. plant performance than nativity. For the retail nurseries, customers were identified as primarily residential purchasers, typically over 40 years in age $(\mathrm{SD}=1.553)$. This was similar in findings to Waterstrat's (1997) study of retail customers as being primarily over 40 years in age. Customers for wholesale nurseries included retail, re-wholesale markets, and nearly half $(47.3 \%)$ sold material to landscape architects or contractors. This is significant in that Waterstrat's study (1997) identified southern landscape architects as the primary specifier in native plant materials for residential and commercial applications. In the southeastern United States, only $3.9 \%$ of purchasers were governmental agencies as found in this study, which is significantly lower than native plant markets in western states where land restoration and reclamation projects comprise a large use of natives by federal and state governments (Hooper, 2003).
When asked the primary reason why they carried native plants, client request was the most significant answer $(25.6 \%)$ followed by ecological reasons $(17.8 \%)$, adaptability to difficult site conditions (16.3\%), and low maintenance rationales (13.2\%) $(S D=1.778)$. This differed considerably from landscape architects being asked the same question, who responded that native plants were mostly used because of their ability to grow in difficult site conditions (Brzuszek et al., 2007).

In this study, producers stated the reasons native plants were requested included: these were specified by the landscape architect/contractor's customers (21.7\%), low maintenance $(17.8 \%)$, ecological reasons (16.3\%), and being best adapted to difficult sites $(15.5 \%)$ (Table 3 ). Not enough customer interest was the most significant reason given as to why they did not sell more native plants (36.4\%) (Table 4). Waterstrat's 
Table 3. Reasons customers purchase native plants as reported by nurseries on a southeastern United States green industry survey on native plant marketing conducted in 2007.

\begin{tabular}{lcc}
\hline $\begin{array}{l}\text { Stated reasons for customers } \\
\text { purchasing native plants }\end{array}$ & $\begin{array}{c}\text { Responses } \\
\text { (no.) }\end{array}$ & $\begin{array}{c}\text { Valid } \\
\text { responses (\%) }\end{array}$ \\
Client request & 28 & 21.7 \\
Low maintenance & 23 & 17.8 \\
Ecological reasons & 21 & 16.3 \\
Best adapted to difficult sites & 20 & 15.5 \\
No answer & 17 & 13.2 \\
Aesthetics or beauty & 12 & 9.3 \\
Other nonstated reasons & 4 & 3.1 \\
All of the above & 2 & 1.6 \\
Drought resistance & 1 & 0.8 \\
Regulatory codes & 1 & 0.8 \\
Total SD = 1.946 & 129 & 100.0 \\
\hline
\end{tabular}

Table 4. Responses to "why nurseries do not sell more native plants in their business" as reported on a southeastern United States green industry survey on native plant marketing conducted in 2007.

\begin{tabular}{lcc}
\hline $\begin{array}{l}\text { Stated reasons why customers } \\
\text { do not purchase more natives }\end{array}$ & $\begin{array}{c}\text { Responses } \\
\text { (no.) }\end{array}$ & $\begin{array}{c}\text { Valid } \\
\text { responses (\%) }\end{array}$ \\
\hline Not enough customer interest & 47 & 36.4 \\
Not familiar with natives & 26 & 20.2 \\
No answer & 19 & 14.7 \\
Natives sell by trends & 15 & 11.6 \\
Too few sources to purchase & 10 & 7.8 \\
Too few species available & 7 & 5.4 \\
Insufficient quantities of plants & 3 & 2.3 \\
Prices are not competitive & 2 & 1.6 \\
Total SD $=2.413$ & 129 & 100.0 \\
\hline
\end{tabular}

survey of southeastern nursery growers (1997) also listed lack of customer interest as the primary reason when asked this same question.

Better consumer education was the number one answer $(54.3 \%)$ as to what would help increase native plant sales at their nursery, followed by better advertising campaigns and having more selection of native species and cultivars. When asked what they thought would be most helpful for customers at the retail level, nursery growers answered again that better consumer education was paramount $(37.2 \%)$, followed by plant tags $(22.3 \%)$, multiple information strategies $(14.9 \%)$, or brochures (13.2\%) (Table 5). Meyer (2005) supported the need for better public education about native plants for market growth. Waterstrat's survey (1997) had contrasting results to this question, listing larger selection and advertising plans as being more significant (26\% and $25.6 \%$, respectively) than consumer education (9.9\%).
For their own education about native plants, most nursery professionals mentioned that growers' catalogs and trade shows were their best and primary sources of information (34.1\% and $17.1 \%$, respectively). Mass media (including magazines, books, and websites) were of secondary use.

Of the top 10 native plant species being sold through their nurseries, respondents listed, in order of response frequency, the following plants: live oak* (Quercus virginiana), red maple* (Acer rubrum), wax myrtle* (Myrica cerifera), southern magnolia* (Magnolia grandiflora), yaupon holly* (Ilex vomitoria), willow oak (Quercus phellos), sweet bay magnolia (Magnolia virginiana), overcup oak (Quercus lyrata), viburnums (Viburnum spp.), and redbud (Cercis canadensis). The species listed with an asterisk above were also identified as among the top 10 native plants used by southeastern landscape architects (Brzuszek et al., 2007). Two hundred seven native species were identified as being grown by nursery respondents in this survey. Tree, shrub, and herbaceous types listed were roughly equal (28.8\%, 25.9\%, 31.7\%; respectively), followed by grasses $(10 \%)$, and vines (3.3\%).

As found in the study of southeastern U.S. landscape architects (Brzuszek et al., 2007), despite a low request rate for native plants by purchasers, the nurseries queried in this study perceived significantly more customer interest in native plants today than there was 5 years ago, representing a shift from minimal to moderate customer interest, as shown in Fig. 2. When asked the dollar value of natives sold through their nursery in 2006, nearly half $(48.4 \%)$ responded as sales being under $\$ 75,000$ ( $\mathrm{SD}=1.741)$. Nearly $13 \%$ estimated 2006 annual sales of native species exceeding $\$ 500,000$, with Texas providing the highest number of responses $(58.3 \%)$. As Texas has a higher number of native plants being produced $(21-40 \%$ of total nursery stock compared with $0-20 \%$ for all other states) and leads in higher sales dollars, this state may be known for availability of natives or being able to meet a larger market supply.

\section{Implications from the study}

Native plants are a growing niche market in the southeastern United States, although they currently account for a small percentage of nursery stock in that region. This study found that growers perceive that customer interest in native plants in the southeastern U.S. market has increased, which is also supported by the observations of landscape architects. As seen from a previous study in this region, this is a continuing trend since the 1990s (Waterstrat, 1997).

If landscape architects and contractors are a large purchaser group of wholesale nursery stock in the southeastern United States, and the number of public consumers specifically asking for native plants is relatively low, the landscape industry is then a large proportion of native plant sales. As noted from the needs of landscape industries in this region, the market for native plants sold could increase if more wholesale nurseries expanded the volume of native plants carried and the diversity of species that are commercially available. 
Table 5. Types of information on native plants that would be beneficial at retail outlets as reported by the southeastern United States green industry in a survey on native plant marketing conducted in 2007.

\begin{tabular}{lcc}
\hline Stated information resources & Responses (no.) & Valid responses (\%) \\
\hline Better consumer education & 45 & 37.2 \\
Individual plant tags & 27 & 22.3 \\
Multiple methods & 18 & 14.9 \\
Brochures & 16 & 13.2 \\
Not sure & 5 & 3.9 \\
Bench tags & 3 & 2.5 \\
Posters & 3 & 2.5 \\
Websites & 3 & 2.5 \\
Periodic information sent & 1 & 1.0 \\
No answer & 8 & - \\
Total SD $=2.997$ & 129 & 100.0 \\
\hline
\end{tabular}

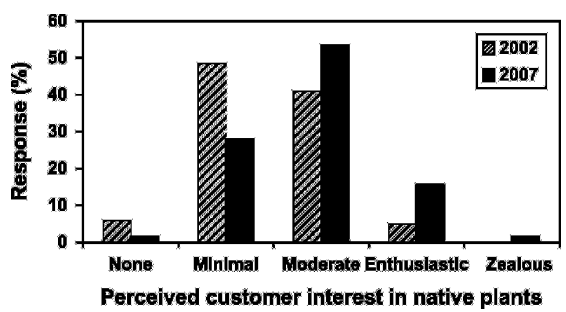

Fig. 2. A comparison of southeastern U.S. customer interest in native plants as perceived by nursery growers $(\mathrm{SD}=\mathbf{0 . 6 8 4})$.

Because most landscape architects and contractors obtain new information about native plants and their availability through the growers catalogs sent to their offices (as does the nursery industry itself), this appears to be a primary vehicle to increase sales to the landscape industry. Small articles and features that highlight new cultivars of native plants, their culture, and ornamental and environmental uses could educate and inspire designers and consumers to select these species for their planting design choices. The landscape industry survey revealed that they prefer to trust nursery growers and others who have experience with the performance of these plants over other sources that may not provide as reliable information.

To further increase the potential of this market, growers suggest that better and more information sources be provided for the general public, particularly through the use of specific marketing campaigns and point-of-purchase information. This type of information is lacking in many of the states studied in this survey. Nonprofit organization programs such as the NWF's American Beauties ${ }^{\text {TM }}$ collection, or statesponsored programs such as the Missouri Grow Native! program may be effective models that southeastern nonprofit, nursery associations, state agencies, or extension organizations could incorporate to better market native plants at the retail level. To better understand the consumer needs of native plants in the southeastern United States, further research needs to be conducted that assesses public interest levels and purchasing of native plants compared with the green industry and landscape architecture responses.

Among the southeastern states, Texas and Florida offer the best public websites on native plant information, as exhibited by the Lady Bird Johnson Wildflower Center in Texas, and the University of Florida Institute of Food and Agriculture Science Extension websites. There is a strong need for centralized native plant information for most other southeastern states, and there are opportunities for nonprofit organizations, state nursery associations, and extension services to supply this information.
Results have also shown that presentations and displays at nursery trade shows are another instrument for growers and retailers to learn about new native plant cultivars. State nursery associations and trade show organizers may increase grower awareness of native plants through educational sessions and distributed media. Nursery associations such as the AFNN and the CNPLX may also provide valuable assistance regarding available native plant species and sources.

\section{Literature cited}

Brzuszek, R.F., R.L. Harkess, and S.J. Mulley. 2007. Landscape architects' use of native plants in the southeastern United States. HortTechnology 17:78-81.

Dillman, D.A. 2000. Mail and internet surveys: The tailored design method. Wiley, New York.

Hamill, N. 2005. Natives near and far. Ornamental Outlook 14(6):31-32.

Hooper, V.H. 2003. Understanding Utah's native plant market: Coordinating public and private interest. Utah State Univ., Logan, Thesis.

Meyer, S.E. 2005. Intermountain Native Plant Growers Association: A nonprofit trade organization promoting landscape use of native plants. Native Plants J. 6(2): 104-107.

National Wildlife Federation (NWF). 2007. American Beauties ${ }^{\mathrm{TM}}$ - National Wildlife Federation. 13 Nov. 2007. <http://www.nwf.org/backyard/american beauties.cfm>.

Norcini, J. 2006. Native plants: An overview. Environ. Hort. Dept., Florida Coop. Ext. Serv., Inst. Food Agr. Sci., Univ. Florida, Document ENH1045.

Schaefer, D.R. and D.A. Dillman. 1998. Development of a standard e-mail methodology. Public Opin. Q. 62:378-397.

Smith, J. 2007. Native plants in native places. 13 Nov. 2007. <http://www. ctahr.hawaii.edu/rnre/Native_Plants_ Public_Places.asp $>$.

Waterstrat, J. 1997. Assessment of the native plant market in the southeastern United States. Mississippi State Univ., Starkville, M.S. Thesis. 